\title{
(6) Digenic inheritance in medical genetics
}

\section{OPEN ACCESS}

- Additional material is published online only. To view please visit the journal online (http://dx.doi.org/10.1136/ jmedgenet-2013-101713).

\section{Correspondence to}

Dr Alejandro A Schäffer, Computational Biology Branch, National Center for Biotechnology Information, National Institutes of Health Department of Health and Human Services, 8600 Rockville Pike, Bethesda, MD 20894, USA:

schaffer@helix.nih.gov

Received 2 April 2013 Revised 24 May 2013 Accepted 28 May 2013 Published Online First 19 June 2013
To cite: Schäffer AA. J Med Genet 2013;50:641-652.

\author{
Alejandro A Schäffer
}

\begin{abstract}
Digenic inheritance (DI) is the simplest form of inheritance for genetically complex diseases. By contrast with the thousands of reports that mutations in single genes cause human diseases, there are only dozens of human disease phenotypes with evidence for DI in some pedigrees. The advent of high-throughput sequencing (HTS) has made it simpler to identify monogenic disease causes and could similarly simplify proving DI because one can simultaneously find mutations in two genes in the same sample. However, through 2012, I could find only one example of human DI in which HTS was used; in that example, HTS found only the second of the two genes. To explore the gap between expectation and reality, I tried to collect all examples of human DI with a narrow definition and characterise them according to the types of evidence collected, and whether there has been replication. Two strong trends are that knowledge of candidate genes and knowledge of protein-protein interactions (PPIs) have been helpful in most published examples of human DI. By contrast, the positional method of genetic linkage analysis, has been mostly unsuccessful in identifying genes underlying human DI. Based on the empirical data, I suggest that combining HTS with growing networks of established PPIs may expedite future discoveries of human DI and strengthen the evidence for them.
\end{abstract}

\section{INTRODUCTION}

Digenic inheritance (DI) has fascinated geneticists since the early 20th century. In the early decades of studies on genetics, the term 'epistatis' was used by some to describe some forms of digenic inheritance, ${ }^{1}$ but in recent decades 'epistasis' has been used to describe a much broader category of locuslocus interactions in polygenic diseases, including but not limited to interactions of loci identified by genome-wide association studies. ${ }^{2}$ This review is a synthesis of knowledge about digenic inheritance in a narrow sense, not about epistatsis in a broad sense.

Defrise-Gussenhoven ${ }^{3}$ suggested more than 50 years ago that there would be many human disease pedigrees showing reduced penetrance when treated in genetic analysis as monogenic, but that the inheritance could be explained more accurately by a two-locus model. The first prediction came true, but few studies of pedigrees with incomplete penetrance consider two-locus analysis, even though good methods have been developed. ${ }^{4-6}$ In this context, 'reduced penetrance' means that while all or almost all affected pedigree members are modelled as having the mutant genotype at the primary locus, one or more relatives with the primary mutant genotype are unaffected; genetic modelling allows for the imperfect correspondence between genotype and phenotype.
The first report of DI in a human disease was in 1994 for retinitis pigmentosa (RP). ${ }^{7}$ This report was convincing because it included data from multiple pedigrees, and the protein products of the two genes had a known interaction. After 1994, there was a trickle of additional DI reports until 2001, which saw prominent reports of human DI in Bardet-Biedl syndrome (BBS), ${ }^{8}$ deafness ${ }^{9}$ and other phenotypes. These discoveries stimulated a trio of influential reviews in 2002-2003. ${ }^{10-12}$ Since 2002, discoveries of human DI have been appearing at a steady pace (see Discussion), but were not reviewed systematically, except for specific diseases, such as deafness ${ }^{13}$ and Hirschprung's disease. ${ }^{14}$

The three reviews and other contemporaneous papers engaged in a lively but inconclusive debate on how to define human DI. Here, I use a narrow, operational definition that inheritance is digenic when the variant genotypes at two loci explain the phenotypes of some patients and their unaffected (or more mildly affected) relatives more clearly than the genotypes at one locus alone. This includes cases where both loci determine who is affected, a substantial change in severity, or a substantial change in age of onset. The definition includes cases in which one locus is the primary locus, and by itself has variable expressivity, as well as cases where the two loci are roughly equal in importance. I generally exclude cases where the inheritance is polygenic with many more than two loci involved. I generally exclude 'modifier loci' that have a modest effect on the phenotype and for which the evidence is only statistical. ${ }^{15}$ For diseases whose aetiology involves more than two genes, formalisms, such as Bayesian networks, may be needed to describe the role of each gene and its variants in the 'cause' of the disease.

In the prominent example of BBS and others in the section on five examples below, a simple deterministic model that explained some pedigrees proved to be too simple for all pedigrees. When large collections of pedigrees are available, probabilistic models that assign higher probabilities to patients who have more mutations will likely fit the collection of data better. The impetus to collect hundreds of patients and fit a statistical genotypephenotype model comes after initial observations of one or a few pedigrees that fit simpler models of multigenic inheritance. Therefore, this review focuses attention on how to find the initial digenic patients and pedigrees.

Besides the lack of recent reviews, another stimulus for this review is the hypothesis that high-throughput DNA sequencing (HTS) would be an enabling technology to accelerate discoveries of human DI. Because HTS makes it possible to sequence many genes simultaneously, disease-relevant mutations in two genes can be discovered in a single experiment. 
HTS does not solve the problem of deciding which mutations are relevant to the phenotype, and doing so is more difficult when the inheritance is digenic as compared with monogenic.

There has been one recent example of HTS enabling a proof of DI. The disease is facioscapulohumeral muscular dystrophy (FSHD) type $2 .{ }^{16}$ The primary locus for both type 1 and type 2 FSHD is DUX4, and that had been discovered by pre-HTS methods. In many pedigrees with type $2 \mathrm{FSHD}$, the penetrance of the DUX4 variant is incomplete. Therefore, Lemmers et al ${ }^{16}$ sought a second locus via HTS. They found that heterozygous, rare variants in the gene SMCHD1 could explain the inheritance pattern in 21/26 individuals in various pedigrees. Patients with a variant at DUX4 and a variant at SMCHD1 are mostly affected, while patients with a variant at DUX4 and wild type at SMCHD1 are mostly unaffected. SMCHD1 controls epigenetic marks affecting gene expression, so the basis for the DI is likely to be a protein-DNA interaction between SMCHD1 and DUX4, affecting the expression of DUX4.

I could not find any other studies in which HTS has facilitated a discovery of human DI, though a second example was published online after this article was submitted. ${ }^{17}$ To investigate why, I started by building a catalogue of human DI examples. Next, I analysed what study designs had been tried. Then, I considered some of the more publicised examples to see if there was anything special about the most replicated cases of human DI. The successes and some not-so-successful examples suggest three lessons that may aid future studies of human DI. In the Discussion, I use an epistemological approach to suggest how HTS and other new technologies may be used to accelerate the pace of future discoveries.

\section{COLLECTION OF EXAMPLES OF HUMAN DIGENIC INHERITANCE}

To collect examples of human digenic inheritance, I used previous reviews, ${ }^{10-14}$ Online Mendelian Inheritance in Man (OMIM), ${ }^{18}$ PubMed, PubMed Central, and Google Scholar. I used the Citation Index to find more examples and to look for replications and refutations of previous publications. The search ended in January 2013. Some items in early reviews were excluded here because: they were for model organisms; they had been subsequently refuted; the evidence for the second locus looks weak; or the second locus is a modifier locus based primarily on statistical evidence. The collection of references on BBS and other ciliopathies is incomplete, since the evidence for and against DI in those disorders has been extensively explored elsewhere. ${ }^{10} 121920$

All DI examples are collected in online supplementary table S1, along with two studies at the bottom in which possible DI of a multisystem syndrome turned out to be two different diseases. The examples that are not primarily replication studies are presented succinctly in table 1 . For DI examples that have been repeatedly replicated, such as CDKN2A and MC1R in melanoma susceptibility, ${ }^{21}$ only a few replicating papers are included. The inheritance at each locus can be usually described as autosomal dominant (AD), autosomal recessive (AR), or X-linked recessive (XLR). The main exception is triallelic inheritance, explained below, in the subsection on BBS. Other examples of possible triallelic inheritance can be found in online supplementary table S1 by searching the two columns titled 'Inh.' for the word 'triallelic'.

Ideal evidence for DI would include identification of the two genes involved in multiple pedigrees with multiple affected individuals in at least one pedigree. The evidence is strengthened by a comparison of the phenotypes of individuals having the mutations in both genes to the phenotypes of individuals with only one gene or the other gene mutated. Ideal digenic pedigrees may be hard to find. Therefore, in a few cases, such as Long QT syndrome (LQTS), the evidence accumulates over multiple studies. $^{22-26}$ Various studies suggested DI based on one or a few patients without pedigree evidence. To evaluate whether genetic linkage analysis (GLA) is useful to find DI, I included studies in which strong evidence of two loci was found by linkage analysis, without requiring that the two genes have been found.

The data about each study include: the loci and genes, whether there was pedigree evidence, whether the study was replicated later, had internal replication only, or mostly replicated a prior study (see online supplementary table S1). Two additional useful pieces of information are: whether the loci are genetically linked, and whether there is any functional relationship between the two genes or their protein products. The functional relationships could be: protein-protein interaction (PPI), protein-DNA interaction, or being on a shared pathway without a known direct interaction. The importance of whether the loci are linked, and whether the genes have any interaction, is considered in the section entitled: 'Three lessons for future studies of human digenic inheritance'.

\section{COMMONLY USED STUDY DESIGNS}

Two experimental study designs predominate among the reported cases of human digenic inheritance. These are illustrated abstractly in figure 1 . I consider one alternative design in this section and another alternative design in the Discussion.

The majority of examples in table 1 and almost all examples in which both genes have been identified are based on a candidate gene (CG) design, proceeding as follows:

1. Identify a small set of genes $G=\left\{g_{1}, g_{2}, \ldots\right\}$ that are mutated, or might be mutated, in monogenic forms of some disease, D, that has locus heterogeneity.

2. Use Sanger sequencing to sequence at least two of the genes in $G$ in a set of patients with disease D and perhaps in their relatives.

3. Identify patients with mutations in two genes.

The evidence from the CG study design is more impressive when relatives having only one of the two genes mutated are unaffected or have a different phenotype than the patients with two genes mutated. Additional experiments to identify how the two genes/proteins interact or reproducing the DI in an animal model $^{27}$ strengthen the evidence.

The CG study design (figure 1A) has been successful, but a limitation is that the genes to sequence must be selected in advance. DI in which mutations in each of the pair of genes lead to no phenotype is nearly impossible to detect by the CG study design.

A second study design, which avoids the need to preselect genes, is based on GLA. The GLA design (figure 1B) proceeds roughly as follows:

1. Identify one or more pedigrees with cases of a disease and preferably with evidence of reduced penetrance (eg, likely dominant inheritance in which some obligate mutation carriers are unaffected).

2. Genotype markers across the genome.

3. Analyse for linkage either one locus at a time or using twolocus linkage analysis.

4. (Ideal but rarely completed) By sequencing, find mutations in one gene in each of the linkage regions.

I could not find a single example where the sequencing step (4) was completed successfully to identify both genes on different chromosomes. Rotor syndrome is one recent successful example of GLA in which the two genes are tightly linked, so linkage analysis was done as if the disease is monogenic. ${ }^{28}$ Also, when the first gene is known, then linkage analysis to find the second locus can 
Table 1 Original, non-overlapping findings of human digenic inheritance

\begin{tabular}{|c|c|c|c|c|}
\hline Disease & Gene/locus1 & Gene/locus2 & Replication & Reference(s) \\
\hline Long QT syndrome (LQTS) & KCNH2/7q & KCNQ1/11p & Yes & 22 \\
\hline LQTS & various LQT genes & various LQT genes & Yes & $23-26$ \\
\hline Deafness & $G J B 2 / 13 q$ & $G J B 6 / 13 q$ & DNA level & 9 \\
\hline Deafness & TECTA/11q & $1 p$ & No & 3031 \\
\hline Pendred syndrome/deafness & $S L C 26 A 4 / 7 q$ & FOXI1/5q & No & 87 \\
\hline Deafness suppression & $1 q$ & $4 q$ & No & 72 \\
\hline Deafness & $\mathrm{CDH} 23 / 10 \mathrm{q}$ & ATP2B2/3p & Partial & 49 \\
\hline Usher syndrome & MYO7A/11q & $3 q$ & No & 88 \\
\hline Usher syndrome & $C D H 23 / 10 q$ & $P C D H 15 / 10 q$ & Yes & 27 \\
\hline Usher syndrome & $P D Z D 7 / 10 q$ & GPR98/5q & Internal & 89 \\
\hline Bartter's syndrome (antenatal w/deafness) & CLCNKA/1p & CLCNKB/1p & Yes & 90 \\
\hline Bardet-Biedl syndrome & $B B S 2 / 16 q$ & various BBS loci & Yes & 8 \\
\hline Bardet-Biedl syndrome & $B B S 4 / 15 q$ & various BBS genes & Yes & 61 \\
\hline Bardet-Biedl syndrome & $B B S 1 / 11 q$ & various $\mathrm{BBS}$ genes & Yes & 62 \\
\hline Joubert syndrome (+ciliopathies) & CEP41/7q & various genes & No & 65 \\
\hline Leber's congenital amaurosis(+ciliopathies) & CEP290/12q & MKKS/BBS6/20p & Internal & 66 \\
\hline Short-rib polydactyly (ciliopathy) & $N E K 1 / 4 q$ & DYNC2H1/11q & No & 67 \\
\hline Nephrotic syndrome & NPHS1/19q & NPHS2/1q & Yes & 68 \\
\hline Hypogonadotropic hypogonadism & PROKR2/20p & $K A L 1 / \mathrm{Xp}$ & Yes & 69 \\
\hline Hypogonadotropic hypogonadism & FGFR1/8p & $N S M F / 9 q$ & Yes & 70 \\
\hline Hypogonadotropic hypogonadism & FGF8-related & FGF8-related & Internal & 71 \\
\hline Hypogonadotropic hypo. (syndromic) & $R N F 216 / 7 p$ & OTUD $4 / 4 q$ & No & 17 \\
\hline Hirschsprung disease & $R E T / 10 q$ & EDNRB/13q & Yes & 91 \\
\hline Parkinson's disease & PARK $7 / 1 \mathrm{p}$ & PINK1/1p & No & 92 \\
\hline Retinitis pigmentosa & PRPH2/6p & $R O M 1 / 11 \mathrm{q}$ & Internal & 7 \\
\hline Glaucoma (earlier onset) & MYOC/1q & CYP1B1/2p & Yes & 93 \\
\hline Waardenburg syndrome/albinism & MITF/3p & $T Y R / 11 q$ & Partial & 94 \\
\hline Oculocutaneous albinism (OCA) & $T Y R / 11 q$ & $O C A 2 / 15 q$ & Partial & 95 \\
\hline Junctional epdermolysis bullosa & COL17A1/10q & $\angle A M B 3 / 1 q$ & No & 96 \\
\hline Disfibrinogenemia (slow clotting) & $F G A / 4 q$ & $F G G / 4 q$ & No & 97 \\
\hline Polycystic kidney disease & PKD1/16p & PKD2/4q & No & 98 \\
\hline Holoprosencephaly & SHHITq & $T G I F 1 / 18 p$ & Internal & 11 \\
\hline Familial hypercholest. suppression & $L D L R / 19 \mathrm{p}$ & $13 q$ & No & 73 \\
\hline Cystinuria & $S L C 3 A 1 / 2 p$ & $S L C 7 A 9 / 19 q$ & Yes & 99 \\
\hline Hyperinsulinemia & PPARG/3p & $P P P 1 R 3 A / 7 q$ & No & 100 \\
\hline Hypercholanemia & $T J P 2 / 9 q$ & BAAT/9q & No & 79 \\
\hline Pheochromocytoma & TMEM127/2q & $16 p$ & No & 3233 \\
\hline Familial exudative vitreoretinopathy & $F Z D 4 / 11 q$ & $F 5 / 1 q$ & No & 101 \\
\hline Factor VIII thromboembolism & $5 q$ & $11 q$ & No & 102 \\
\hline PMP22-related neuropathies & PMP22/17p & various genes & Partial & 103104 \\
\hline Charcot-Marie-Tooth disease (non-PMP22) & MFN2/1p & GDAP1/8q & No & 105 \\
\hline Emery-Dreifuss muscular dystrophy & $L M N A / 1 q$ & $E M D / X q$ & Yes & 106 \\
\hline Porphyria (acute) & various genes & $H F E / 6 p$ & Pathway level & 107 \\
\hline Porphyria (acute) & UROD/1p & $H M B S / 11 q$ & Pathway level & 108 \\
\hline Porphyria (acute) & $C P O X / 3 q$ & $A L A D / 9 q$ & Pathway level & 109 \\
\hline Epilepsy w/febrile seizures & $1 q$ & $18 q$ & No & 110 \\
\hline Hemachromatosis & $H F E / 6 p$ & HAMP/19q & No & 111 \\
\hline Progressive external ophthalmoplegia & C10orf2/10q & $P O L G / 15 q$ & No & 112 \\
\hline Epilepsy w/febrile seizures & $S C N 1 A / 2 q$ & $S C N 2 A / 2 q$ & No & 113 \\
\hline Photosensitivity in epilepsy & $7 q$ & $16 p$ & No & 114 \\
\hline Split-hand/foot malformation & $1 q$ & $6 q$ & No & 115 \\
\hline Iminoglycinuria & $S L C 36 A 2 / 5 q$ & $S L C 6 A 20 / 3 p$ & Internal & 116 \\
\hline Keratoconus & $1 p$ & $8 q$ & No & 117 \\
\hline Limb-girdle muscular dystrophy & $S G C B / 4 q$ & $S G C D / 5 q$ & No & 118 \\
\hline Ullrich congenital muscular dystrophy & COL6A1/21q & COL6A2/21q & No & 119 \\
\hline Pseudoxanthoma elasticum & $A B C C 6 / 16 \mathrm{p}$ & $G G C X / 2 p$ & No & 120 \\
\hline Hereditary motor neuropathy & $D S C L 2 / 11 q$ & $16 p$ & No & 121 \\
\hline Cleft lip & $1 q$ & $2 p$ & No & 122 \\
\hline Fuchs corneal dystrophy & ZEB1/10p & $9 p$ & No & 29 \\
\hline
\end{tabular}


Table 1 Continued

\begin{tabular}{lllll}
\hline Disease & Gene/locus1 & Gene/locus2 & Replication & Reference(s) \\
\hline Axenfeld-Rieger syndrome & PITX2/4q & FOXC1/6p & No & No \\
Colorectal cancer & MUTYH/1p & OGG1/3p & Internal & 124 \\
Rotor syndrome (hyperbilirubinemia) & SLCO1B1/12p & SLCO1B3/12p & No \\
Dent's disease & CLCN5/Xp & OCRL/Xq & Internal \\
Facioscapulohumeral musc. dystrophy & DUX4/4q & SMCHD1/18p & No & 78 \\
Epidermolysis bullosa simplex & KRT5/12q & KRT14/17q & Yes & 16 \\
Melanoma susceptibility & CDKN2A/9p & MC1R/16q & Internal & 21 \\
Hypotrichosis (nonsyndromic) & CDH3/16q & $12 q$ & 75
\end{tabular}

A larger table including more rows with overlapping findings and more columns, such as the mode of inheritance at each locus, can be found in online supplementary table S1. Gene names are currently Hugo Genome Nomenclature Committee-approved names, not necessarily the gene names in the original publication. In some cases, the original study (eg, reference ${ }^{11}$ ) reported multiple pairs of genes, and there is one representative pair in the table. Options for the Replication column (and their meanings) include: Yes (replicated in a later study), Internal (multiple pedigrees in the original study but no later study), Partial (one of the genes participates in some other documented human DI), Pathway level (other genes in the same pathway participate in other documented human DI), DNA level (applies only to GJB2/GJB6 and is explained in the text, No. Examples discussed in the text are put at the top of the Table. The replication references are given in online supplementary table S1.

be done using a monogenic linkage analysis, conditional on the mutation status or haplotype status at the first locus. ${ }^{6} 29$ Two examples where the GLA design succeeded to find the gene at one of two loci are in deafness 3031 and pheochromocytomas. ${ }^{32} 33$

Since GLA has been repeatedly successful in setting up the identification of genes causing monogenic diseases, the failure of the GLA design in DI merits investigation. There exist at least three software packages that can do two-locus linkage analysis: TLINKAGE, ${ }^{34}$ SUPERLINK ${ }^{35}$ and GENEHUNTER-TWOLOCUS. ${ }^{5}$ Most of the studies that used two-locus linkage analysis used GENEHUNTER-TWOLOCUS. The mathematical basis for twolocus linkage analysis is that the test statistic, such as a Logarithm of ODds (LOD) score or an NonParametric Linkage (NPL) score typically used to find single disease loci, can be generalised to simultaneous analysis of two disease loci and the genotypes at unlinked marker loci can be combined. ${ }^{5}$ There has been considerable research concerning penetrance models for two-locus linkage analysis, which are needed when the test statistic is the two-locus LOD score. ${ }^{1} 436-$ 39 Thus, the difficulty appears to be due to some unknown gap between theory and reality. One possibility is that human pedigrees with adequate power are hard to find.

The advent of HTS facilitates a third study design (HT):

1. Sequence the exomes or the genomes of a series of patients and their relatives.

2. Identify pairs of genes $\left(g_{1}, g_{2}\right)$ that are recurrently mutated in patients.

3. Compare the sequences of $g_{1}$ and $g_{2}$ in patients and their unaffected relatives.

Since the mutated genes $g_{1}$ and $g_{2}$ may not be functional candidates, some functional experiments would be needed to show the molecular basis of the DI. A major difficulty in human studies is that one has to sample the relatives who are available. Animal models can mitigate this difficulty. One advantage of the HT design is that one can reconstruct haplotypes to see if multiple nearby mutations are on the same or opposite alleles ${ }^{40-42}$ which is relevant below in the section on three lessons.

I could not find a DI study in which the HT design had identified both genes. Cullinane $e t a l^{43}$ found two disease-causing mutations in a single experiment, but that patient had two monogenic diseases. In the example of FSHD, the first gene, DUX4, had already been found before HTS was applied to find the second gene. ${ }^{16}$

\section{FIVE EXAMPLES WITH POSSIBLE REPLICATION}

In this section, I summarise the understanding of possible digenic inheritance of five phenotypes where one could consider that the original claim has been replicated. Some are selected to foreshadow later sections. All five phenotypes occur usually in monogenic forms with locus heterogeneity. Via the CG paradigm, patients with mutations in pairs of the known genes were identified. Surprisingly, I could not find replications of the seminal finding of DI in non-syndromic $\mathrm{RP}^{7}$ though there are many known RP genes. BBS, which is the most studied phenotype with DI does include retinal disease in the phenotype.

\section{Deafness}

Similar to RP, deafness is an excellent candidate for DI because there are dozens of known genes that cause monogenic deafness. Additionally, there are animal models of DI for either nonsyndromic or syndromic deafness. ${ }^{14} 44$ Considerable information is known about protein complexes that function in the inner ear, and hence, pairs of proteins in these complexes are good candidates for DI. Finally, in some societies, there is assortative mating among deaf individuals or close relatives. ${ }^{45}$ Assortative mating may lead to pedigrees in which multiple deafness-related alleles cosegregate. ${ }^{46}$

Table 1 shows five different entries for deafness, three for Usher syndrome (deafness and blindness), and one for a form of Bartter syndrome (salt wasting) that includes deafness. Perhaps the most compelling among these is the combination of $\mathrm{CDH} 23$ and PCDH15 causing digenic Usher syndrome because it has been replicated and there is an animal model. ${ }^{27} 47$ However, some of these patients may be better classified as having recessive, monogenic inheritance at $P C D H 15$; moreover, $P C D H 15$ has additional exons that were not sequenced in those patients found to have one mutation in each of $\mathrm{PCDH} 15$ and $\mathrm{CDH} 23$, and therefore, a second PCDH15 mutation may have been missed. ${ }^{48}$ An overlapping case where the human DI matches an animal model is the combination of $\mathrm{CDH} 23$ and $A T P 2 B 2$ in a single human pedigree. ${ }^{49}$

The most studied example of DI in deafness is the combinations of GJB2 and GJB6 $6^{50-52}$ both of which are also monogenic deafness genes encoding connexins that function in a complex. The evidence for DI among the genes encoding proteins in this connexin complex was strengthened by a report of DI in deafness with mutations in GJB2 and GJB3. ${ }^{53}$ However, Rodriguez-Paris et $a l^{5455}$ have shown that the GJB2/GJB6 case is actually monogenic recessive $G J B 2$-caused deafness at the RNA and protein levels. The GJB6 mutations are deletions that inactivate the second GJB2 allele, which is nearby on chromosome 13 . Further evidence that a regulatory element outside GJB2 regulates the expression of GJB2 and GJB6 is given via allele-specific 
Figure 1 Idealised study designs. One of two study designs have been used in almost all published discoveries of human digenic inheritance: (A) An idealised example of the candidate gene design (CG) to search for DI: Displayed is an idealised view of this with four CGs for a certain disease: $G_{1}, G_{2}, G_{3}, G_{4}$. In practice, there could any number $>1$ of genes. Individuals with mutations (mut) in two genes are always affected (black square or circle), but individuals with wild type (wt) sequence for thee out of four genes may or may not be affected (variable expressivity of the mutation, white squares or circles). The CG design may include some close relatives. (B) The genetic linkage design: This design is based on studies of one or more pedigrees. Here, $\mathrm{m}_{1}$ and $m_{2}$ could represent either unusual marker haplotypes or mutations in a multigeneration pedigree. Either $m_{1}$ or $m_{2}$ could show linkage to the disease with reduced penetrance in a similar but larger pedigree, but a two-locus/ digenic model explains the data better. In particular, among individuals carrying exactly one of $\left\{m_{1}, m_{2}\right\}$, some are affected and some are unaffected.
A

Idealized candidate gene (CG) to search for DI

\begin{tabular}{|l|l|l|l|}
\hline $\mathbf{G}_{1}$ & $\mathrm{G}_{2}$ & $\mathrm{G}_{3}$ & $\mathrm{G}_{4}$ \\
\hline mut & mut & wt & wt \\
\hline wt & mut & mut & wt \\
\hline wt & wt & mut & mut \\
\hline mut & wt & wt & mut \\
\hline mut & wt & wt & wt \\
\hline mut & wt & wt & wt \\
\hline wt & mut & wt & wt \\
\hline wt & mut & wt & wt \\
\hline wt & wt & mut & wt \\
\hline wt & wt & mut & wt \\
\hline wt & wt & wt & mut \\
\hline wt & wt & wt & mut \\
\hline
\end{tabular}

B

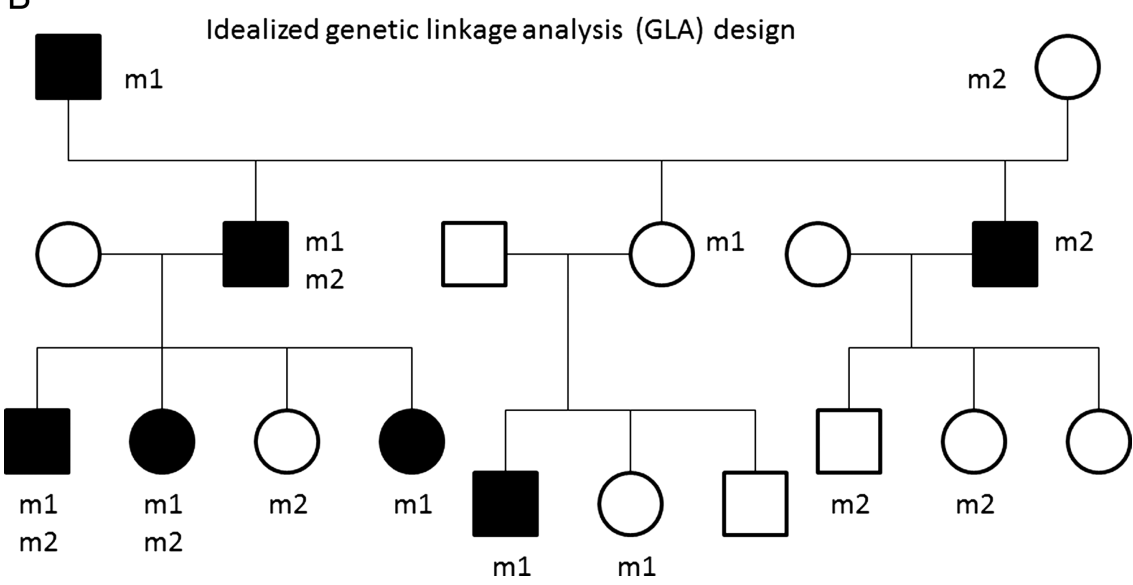

expression assays of a unique deafness-associated haplotype on $13 \mathrm{q} .{ }^{46}$ The GJB2/GJB3 example cannot be similarly refuted because GJB3 is on chromosome 1.

\section{Long QT syndrome}

LQTS is a disease in which patients may suffer cardiac arrhythmias and sudden death. Inheritance is often autosomal dominant, but many pedigrees have incomplete penetrance. LQTS has substantial locus heterogeneity and several pairs of the protein products of LQTS genes interact. The combination of locus heterogeneity, PPIs, and variable expressivity of single gene mutations makes LQTS a good candidate for the model that what looks like reduced penetrance under monogenic inheritance masks DI. The way to follow-up is to compare DNA sequences of affected and unaffected relatives sharing the disease-associated mutation in the first gene. The follow-up can be done by looking either at a few CGs by Sanger sequencing, or many genes by HTS.

For LQTS, the CG design led to the finding that many LQTS patients have mutations in two of the known genes, such as KCNQ1/KCNE1，KCNQ1/KCNH2, KCNH2/KCNE1，SCN51/ KCNE1 and other pairs. ${ }^{22-26}$ The penetrance could be increased either by having a second mutation in one LQTS gene or two heterozygous mutations in different genes. ${ }^{23} 24$ All patients with two mutations manifest the disease, often with earlier onset; the distinction between the two-mutation individuals and the one mutation individuals is statistically significant. ${ }^{23}$

\section{BBS and other ciliopathies}

The phenotype of BBS typically includes six aspects: renal anomalies, polydactyly, obesity, retinal defects, developmental 
delay and hypogonadism. Patients are usually diagnosed when at least four symptoms are detected. There is phenotypic overlap between BBS and many other syndromes, including the next two examples. Considering the unusual combination of symptoms, it is surprising that there have been at least 15 genes identified that can cause monogenic BBS with AR inheritance.

When the first BBS genes were found, the function of the encoded proteins was poorly understood. Later studies have shown that these proteins are involved in the formation and function of cilia, primitive sensory organelles present in many cell types. ${ }^{56}$ Primary cilia are non-motile, while other cilia are motile because they have a flexible microtubule configuration. ${ }^{56}$ BBS and overlapping syndromes, such as Joubert syndrome and Meckel-Gruber syndrome, are called 'ciliopathies'. ${ }^{56}$ The phenotypic spectrum of ciliopathies is broad and may include holoprosencephaly, ${ }^{57} 58$ for which DI has been proposed. ${ }^{11}$ Biochemical studies identified two protein complexes containing seven and three of the $15+$ BBS proteins. ${ }^{59}{ }^{60}$ The protein complexes increase the potential for DI as one could imagine that defects in two of the proteins would be more deleterious than a defect in only one protein.

Before the cilia function and BBS complexes were discovered, Katsanis and colleagues energised the study of BBS and DI by proposing that the inheritance of BBS is triallelic in some pedigrees. ${ }^{8}$ Triallelic inheritance means that any combination of three deleterious alleles at two BBS loci, but not three heterozygous mutations at three loci, are sufficient to cause BBS. Triallelic inheritance was also supposed to indicate that there would be individuals with 'only' a biallelic mutation at one BBS locus who would have no phenotype or a milder phenotype. The triallelic inheritance hypothesis has been controversial because few pedigrees in which three mutant alleles are necessary have been reported. ${ }^{20}$ Early attempts to test the triallelic inheritance hypothesis found that only a small minority of BBS families had exactly two mutant alleles at one locus and a third mutant allele at a second locus. ${ }^{61-63}$ The distribution of mutations is more variable, and the early studies are hard to interpret now because they could only test the subset of BBS genes known at the time of the study. The finding that many BBS patients have mutations in two or more BBS genes has been replicated many times (table 1, see online supplementary table S1). Some BBS patients have as many as five variant alleles in different BBS genes. ${ }^{19}$

Some have argued that the large number of BBS genes and high carrier frequencies in some populations suffice to explain the high frequency of patients with two or more BBS genes, without claiming DI. ${ }^{20}$ The weakness in this argument is that it could be even more applicable to diseases such as blindness, deafness and heart disease that have high locus heterogeneity, but only some specific instances of DI as described above. More problematic to the argument for DI in BBS is that as more patients with mutations in two BBS genes have been discovered, no pattern has emerged to explain which pairs of genes have mutations simultaneously. One could have hypothesised either a 'logical AND' model (the two proteins mutated should be preferentially in the same protein complex) or a 'logical OR' model (the two proteins mutated should be preferentially in different ciliary protein complexes), but neither model fits the BBS mutation data.

The identification of possible DI in BBS has stimulated the search for DI in diseases with phenotypic overlap (see the next two subsections). It has also stimulated the search for modifier genes ${ }^{64}$ and for examples of DI in other ciliopathies. ${ }^{65-67}$

\section{Nephrotic syndrome}

Nephrotic syndrome is a kidney disease in which essential proteins are lost into urine. There is phenotypic similarity with the renal aspect of BBS and other ciliopathies, such as Joubert syndrome. Two of the various monogenic forms of nephrotic syndrome are due to mutations in NPHS1 on 19q encoding nephrin and NPHS2 on 1q, encoding podocin. Koziell et al ${ }^{68}$ identified three families in which there is triallelic inheritance, and those individuals with three deleterious alleles have a more severe form called 'focal segmental glomerulosclerosis' (FSGS). The two proteins, nephrin and podocin, have a direct interaction. This finding was replicated exactly and in a more general form by finding FSGS patients with three deleterious alleles in several pairs of CGs: NPHS1/NPHS2, CD2AP/NPHS2, WT1/NPHSA (see online supplementary table S1). It is interesting that the initial discovery was made in a kidney disease shortly after Katsanis et al proposed triallelic inheritance for BBS. It shows, retrospectively, how one finding of DI might provide impetus for another. The nephrotic syndrome example and the next example suggest the hypothesis that diseases with weak phenotypic similarity to BBS may be good candidates to have DI.

\section{Hypogonadotropic hypogonadism}

Hypogonadotropic hypogonadism $(\mathrm{HH})$ is diminished function of the sexual organs associated with deficient secretion or action of the hypothalamic gonadotropin-releasing hormone $(\mathrm{GnRH})$, which controls the pituitary gonadotropins and, thereby, gonadal function. The non-sydromic form is called 'idiopathic HH' (IHH). There is also a widely studied syndromic form (different from BBS) called Kallman syndrome in which $\mathrm{HH}$ is combined with anosmia.

The initial report of DI in $\mathrm{HH}$ focused on cases with mutations in the ligand-receptor gene pair PROK2 and PROKR2, and also reported one patient with heterozygous mutations in both PROKR2 and the known gene Kallman syndrome gene KAL1. ${ }^{69}$ The pairing of PROK2 and PROKR2 is understandable since they form a receptor-ligand pair, but the mechanism of PROKR2/KAL1 digenic inheritance remains unclear.

Pitteloud $e t a l^{70}$ used the CG design with additional $\mathrm{HH}$ genes and found more examples of DI including the gene pairs FGFR1/NSMF and FGFR1/GNRHR. The general finding of DI in $\mathrm{HH}$ has been replicated multiple times (see online supplementary table S1). However, the number of known patients with two genes mutated is small relative to the number of CGs. Thus, as in BBS, no pattern as to which pairs of genes are mutated together is discernible.

While this manuscript was under review, two more studies showing digenic inheritance in $\mathrm{HH}$ were published. By a generalisation of the CG design, Miraoui et $a l^{71}$ showed that some non-syndromic $\mathrm{HH}$ patients and Kallman syndrome patients have heterozygous mutations in two genes in an FGF8-related pathway. Using HTS, Margolin et al ${ }^{17}$ found homozygous mutations in RNF216 and OTUD4 in three consanguineous siblings with a syndromic form of $\mathrm{HH}$. Using a zebrafish model, they showed that RNF216 and OTUD4 have a functional interaction, but they could not find any functional relationship between RNF216 and OTUD4 and the genes mutated in non-syndromic $\mathrm{HH}$.

\section{THREE LESSONS FOR FUTURE STUDIES OF HUMAN DIGENIC INHERITANCE}

From the catalogue of examples of digenic inheritance, three lessons can be derived to inform future studies. The first two 
are subtle enough that they were not explicitly highlighted in previous reviews. ${ }^{10-12}$ The third lesson is not new, but some of its implications have not been mentioned in previous reviews and are explored in the Discussion.

\section{Lesson 1: in the digenic inheritance examples found to date, the variant genotype at the second locus usually increases disease risk}

The definition of DI in the Introduction does not specify whether the variant genotype at each locus increases or decreases the disease risk. In the study of monogenic diseases, it is usually understood that the variant genotypes at the disease locus do increase the risk. One can extend this assumption to require that in DI, the locus designated as first also has the property that the variant genotype increases the disease risk. It is possible, however, that the variant genotype at the second locus decreases the disease risk. In some early definitions of epistasis, it was required that the second locus suppresses the (traitcausing) effect of the first locus. ${ }^{1}$

Theory differs from practice in the role of the second locus because table 1 shows only three examples of human DI in which the variant genotype at the second locus is definitively suppressive. The first example is deafness in which the first locus is recessive and on $1 \mathrm{q}$, and another recessive locus on $4 \mathrm{q}$ cancels the effect of the first. ${ }^{72}$ This example was found by GLA of a large pedigree. The finding has not been replicated, and the genes underlying the two loci have not been identified. The second example is familial hypercholesterolaemia with a primary mutation in the $L D L R$ gene on $19 \mathrm{p}$ and a recessive locus on $13 \mathrm{q}$ that mitigates the effects of the LDLR mutation. ${ }^{73}$ In this example, like the first, the suppressive locus was found by linkage analysis of a single pedigree, and the gene has not been reported, but there is other evidence of a cholesterolrelated locus on $13 \mathrm{q}^{74}$ In the third example, the disease is hypotrichosis due primarily to mutations in $\mathrm{CDH} 3 .^{65}$ Previously reported cases of hypotrichosis and mutations in $\mathrm{CDH} 3$ are all syndromic. In two pedigrees, a locus on $12 \mathrm{p}$ identified by GLA mitigates the hypotrichosis to make it non-syndromic. ${ }^{75}$

Recently, Rachel and colleagues suggested a possible fourth example. ${ }^{66}$ In this example, the two genes, CEP290 and MKKS (also known as BBS6), were identified by the CG method and MKKS has already been suggested to participate in DI of BBS. The disease is Leber's Congenital Amaurosis (LCA) that is often caused by biallelic mutations in CEP290. Biallelic mutations in CEP290 cause a spectrum of ciliopathies, along which LCA is mild because it affects only the eyes. A surprising percentage of LCA patients had heterozygous mutations in $\mathrm{MKKS}{ }^{66}$ Rachel et $a l^{66}$ proposed that the MKKS mutations mitigate the effect the CEP290 mutations, perhaps 'reducing' the disease severity. This study showed that the two proteins, CEP290 and MKKS, have a direct interaction and constructed a mouse model supporting the DI. The last piece of the proof, which is not reported in the study, would be human pedigrees in which multiple relatives have the same biallelic CEP290 mutations, and relatives with an $M K K S$ mutation have a milder phenotype than relatives without an $M K K S$ mutation.

The predominance of cases in which the second locus variant genotype increases risk reflects a bias of the CG design. If more cases of DI are found by HTS, then a greater percentage may have a second locus that reduces the risk. When the variant genotype at the second locus reduces the risk, that variant genotype is going to be found in unaffected or more mildly affected individuals. Therefore, when using the GLA design or HTS or other designs, it is important to sequence unaffected and mildly affected relatives.

Another approach to identifying a second locus that decreases the risk caused by the variant genotype at the first locus is to compare expression of genes in affected and unaffected relatives with the mutant genotype at the first locus, and this was attempted with some success for spinal muscular atrophy. ${ }^{76}$ One advantage of this approach is that it is unbiased as to which set of relatives will have the unusual expression that is sought. A second advantage of the expression approach is that if the differential expression is found, then that result is closer to a functional experiment than sequence differences would be. ${ }^{76}$ However, the corresponding disadvantage is that it may be difficult to determine whether the expression difference between 'affecteds' and 'unaffecteds' is due to nearby (in cis) sequence differences, or due to differences in some other unlinked gene (in trans). ${ }^{76}$

\section{Lesson 2: when the two loci are linked, the proof is more complicated}

A disproportionate number of the locus pairs in online supplementary table S1 are genetically linked. This includes pairs that are closely linked (SLCO1B1 and SLCO1B3 in Rotor syndrome ${ }^{28}$ ) and examples with weaker linkage (LRP5 and FZD4 in familial exudative vitreoretinopathy ${ }^{77}$ ). When the two mutations are on the same haplotype, but the linkage is weak, one has a chance to find crossover events between the two genes. If such a crossover is present, then a close relative may have only one of the two gene mutations, and one can compare phenotypes between the individuals having one gene mutated and the individuals having both genes mutated. It is useful to divide the linked situations into four categories by inheritance.

The first category is AR inheritance at both loci (eg, Rotor syndrome). In this category, it is hard to prove that a biallelic mutation in one gene does not suffice to cause the disease. In the case of Rotor syndrome, the proof included multiple pedigrees in which all patients had biallelic mutations in both genes, animal models and identifying other human subjects who had biallelic mutations in only one of the genes and were unaffected. $^{28}$

The second category is AD or XLR inheritance at both loci with the two mutations on the same haplotype (in cis). An XLR example is Dent's disease (CLCN5 and OCRL). ${ }^{78}$ Again, it is difficult to prove that one mutation/gene does not suffice to cause the disease. Another problem for $\mathrm{AD}$ inheritance is to evaluate whether all patients have both mutations in cis, and if so, why? It should not matter at the protein level whether the mutations are in cis or in trans, but it does matter for ascertainment. If the mutations are in cis, then they can be transmitted over multiple generations, and the inheritance will appear to be $\mathrm{AD}$ (figure $2 \mathrm{~A}$ ). One can ascertain large pedigrees that will achieve high LOD scores assuming a single dominant locus. For such pedigrees, HTS should help find the DI because HTS can find both mutated genes on the haplotype in a single experiment.

The third category is AD inheritance at both loci with the two mutations on opposite haplotypes (in trans). This differs from the second category because the inheritance will appear to be AR (figure 2B). The affected children would typically all be in one generation. The proof can be easier than in the in cis category because, typically, the patient(s) would inherit one mutation from each parent and the parents would be unaffected or have a milder phenotype. The proof can be harder because it is harder to find large pedigrees. If all the paired mutations are in 


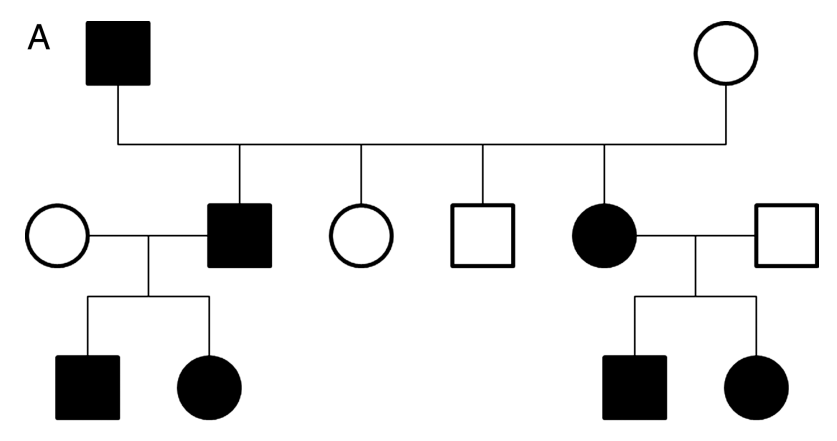

Typical pedigree with linked mutations in cis

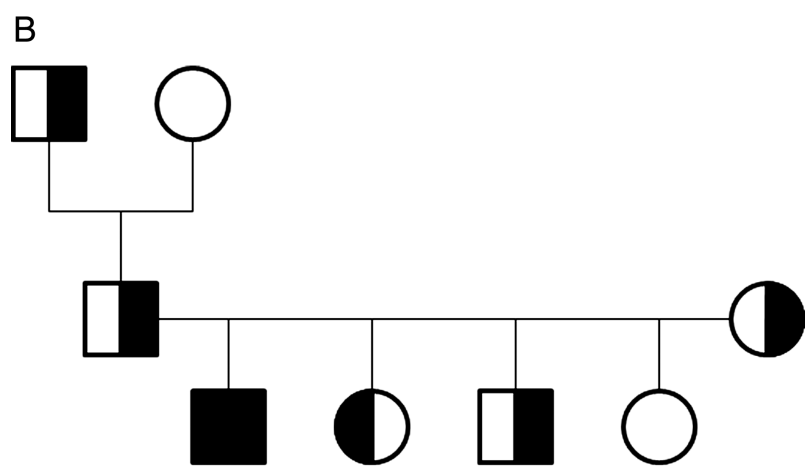

Typical pedigree with linked mutations in trans

Figure 2 Idealised pedigrees for genetically linked loci. Typical pedigrees for digenic inheritance with two linked loci having heterozygous variants either in cis or in trans have a different structure. (A) When the loci are in cis, the inheritance looks like autosomal dominant monogenic inheritance in that pedigree, but high throughput sequencing make it possible to discover both mutations in one experiment. (B) When the loci are in trans, the inheritance may appear as autosomal recessive as is seen in deafness with simultaneous GJB2/ GJB6 mutations. The half shading is to indicate that in some cases of digenic inheritance (eg, long QT syndrome) some individuals with one mutation are affected.

trans, one should wonder why no patients with the mutations paired in cis can be found. To distinguish the second and third categories, it is important to have parental DNA samples; sequencing parental DNA usually determines whether the mutations are in cis or in trans.

The case of GJB2/GJB6 provides a cautionary example of why one should be sceptical if the mutations are always in trans. Because there were only two distinct GJB6 mutations participating in the DI, ${ }^{9}{ }^{50-52}$ it was plausible that there was a founder effect, and GJB2 mutations rarely arose on the haplotypes with either GJB6 deletion. This explanation is incorrect. Each GJB6 deletion disrupts expression of the apparently wild type GJB2 allele on the same haplotype. ${ }^{54} 55$ Thus, at the mRNA and protein levels, the deafness is due to monogenic recessive GJB2 mutations. For gene sequencing, however, it remains useful to consider the inheritance as digenic.

The fourth category is $\mathrm{AR}$ at one locus and $\mathrm{AD}$ at the other locus. One example in the online supplementary table S1 is hypercholanemia with biallelic mutations in TJP2 and heterozygous mutations in BAAT. ${ }^{79}$ These two genes are weakly linked, so one can consider the data as if they were on distinct chromosomes. This example comes from an isolated population and has not been replicated in other populations, so genetic drift may have brought the two mutations together.

In a study design that combines GLA with HTS, there would be a possibility of finding two mutated genes in the interval of genetic linkage. In this circumstance, investigators may apply Occam's razor and try to 'pin the blame' on one gene. Examples in table 1 show that this reductionism can be flawed in two different ways. Either the inheritance can be digenic ${ }^{28}$ or there can be two different diseases in the pedigree each caused by a different gene (eg, cone rod dystrophy and deafness ${ }^{80}$ ).

Lesson 3: protein-protein interactions are an important type of evidence for digenic inheritance

Many of the entries in online supplementary table S1 for which both genes are known are associated with a direct PPI between the gene products. In some cases, the investigators did the PPI experiments themselves because the interaction was not in a database of PPIs. In principle, having two mutations in interacting proteins could be either a 'double hit' or compensatory. ${ }^{8}$ Lesson 1 is that the double hit situation is much more common than the compensatory situation.

Shoemaker and Panchenko ${ }^{81}$ reviewed both in vitro methods for finding new PPIs and databases for searching known PPIs. Laboratory methods include: nuclear magnetic resonance, yeast two-hybrid, coimmunoprecipitation, tandem affinity-purification mass spectroscopy (TAP-MS), protein microarrays, fluorescence resonance energy transfer, atomic force microscopy and others. Useful databases of known interactions include Biogrid, MINT, HPRD, STRING, IntAct. A useful resource that collects and organises other database resources is iRefIndex (http://irefindex. uio.no/wiki/iRefIndex), ${ }^{82}$ which can be searched using iRefWeb (http://wodaklab.org/iRefWeb). ${ }^{83}$ Two limitations of the iRefIndex data downloads are: (1) they refer to genes by UniProt records, which change over time and (2) when the same interaction is included in various sources, the duplicates are not necessarily consolidated. To address these limitations, Stojmirović and Yu developed a parser ppiTrim ${ }^{84}$ whose results identify the genes according to their more stable integer identifiers in NCBI's Entrez gene database. The ppiTrim output files are available at ftp://ftp.ncbi.nih.gov/pub/qmbpmn/ppiTrim/datasets/.

The files whose names start with 9606 contain human data. One complication in evaluating PPI data is that two proteins may function together in a complex, without a direct interaction.

\section{DISCUSSION}

Because HTS sequences many genes in the same experiment, HTS leads frequently to the discovery that a patient has variants in multiple genes that are potentially disease-associated. When the number of patients is small or there is only one pedigree, even sophisticated bioinformatics filtering methods applied to HTS data can leave two or more candidate causal genes and variants. ${ }^{85}$ It may be advisable to consider the possibility of DI in such multicandidate cases, especially if the phenotype is novel. Geneticists using Sanger sequencing (one gene at a time) often stopped looking for mutations even if the genotype-phenotype correlation based on one mutant gene was imperfect, and the finding of an additional mutant gene could explain the observed phenotypes better via DI. In this review, we focused on the distinction between two genes mutated versus one gene mutated because in making that distinction, the methods of proving causality change. The medical geneticist is faced with the general question: Do the variants at both genes together explain the phenotype better than the variant at one gene? Sometimes, the 
answer will be 'yes, because the patient has two monogenic diseases simultaneously'. ${ }^{38}$ Here, the focus is on cases where the answer is 'yes, because there is DI of one disease'. I was surprised to find only one study through 2012 where HTS led to discovery of DI. ${ }^{16}$ Why so few?

There are three overlapping reasons. First, it is possible that there are not that many cases of human DI. Figure 3 shows the number of new (not replication) reports per year of DI in table 1. The rate of discovery has not increased since 2001. Since the number of monogenic diseases with locus heterogeneity is increasing, and the number of genes contributing to the heterogeneity is increasing, one would expect the number of cases of DI detected by the CG design to be increasing as well, but this is not so. DI is near one end of a spectrum of mechanisms by which combinations of mutations increase disease risk; as more and more of these disease mechanisms are discovered, ${ }^{86}$ attention to DI may be diluted.

A second possibility is that more cases of DI involve PPIs and that should be the starting point to find the genetic evidence. Badano $e t a l^{64}$ pioneered the following PPI design to find cases of DI:

1. Choose $g_{1}$ encoding $p_{1}$ as a gene of interest in disease, D, based on past discoveries.

2. Use extensive yeast two-hybrid assays to find protein partners of $p_{1}$.

3. For each partner $p_{i}(i>1)$ encoded by gene $g_{i}$, sequence $g_{i}$ in patients who carry mutations in $g_{1}$.

HTS increases the throughput at step 3 because all the genes can be sequenced in parallel. Techniques more reliable than yeast 2-hybrid assays have been developed to find protein partners. ${ }^{81}$ In silico databases of known and predicted protein interactions are growing rapidly, ${ }^{81}$ making it possible to search among all genes mutated, for pairs of genes encoding protein partners. During my formal literature search, I could not find a second instance in which the PPI design was used to find human DI, but an interesting example in $\mathrm{HH}$ was published while the manuscript was being refereed. ${ }^{71}$ Some of the later discoveries in online supplementary table S1 could have been made by the PPI design, but were made by the CG design instead.

This suggests a third possible explanation. The complexity of DI transcends the genetics. To construct a compelling proof that the inheritance is digenic rather than monogenic may require a multidisciplinary team that can apply techniques to understand the two genes and proteins specifically and their interaction. If we consider

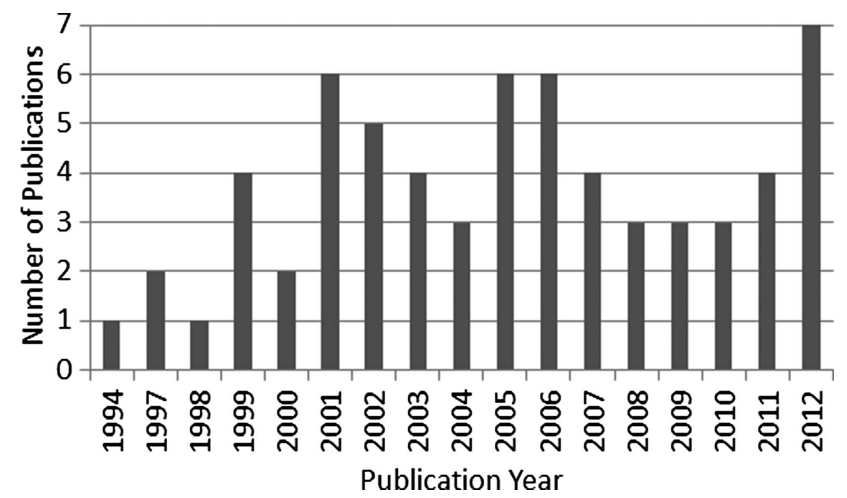

Figure 3 The pace of digenic inheritance discoveries. Numbers of new (not replication) discoveries of human digenic inheritance published per year during 1994-2012. The numbers were tabulated automatically from a version of table 1 that had an extra column including year of publication. two of the more exciting findings of 2012, ${ }^{16} 66$ the techniques they used include: double knockout mice, morpholino studies in zebrafish, genotyping and haplotype analysis, expression and RNA interference experiments, methylation studies, splicing experiments, chromatin immunoprecipitation, electron microscopy, yeast twohybrid experiments, transfection of genes and so on. It is challenging to assemble a scientific team with expertise in all these procedures. The need to assemble these multidisciplinary teams could explain the predominance of the ciliopathies among the studies of DI. Several research groups studying ciliopathies have combined animal models and extensive cell biology experiments in the same study. ${ }^{64}$ ${ }^{66}$ Once such a team is assembled, there may be other exciting problems to work on instead of identifying new examples of human DI, such as defining the PPIs and biochemical pathways that underlie the DI. ${ }^{5960}$ In particular, we seem to be closer to a consensus about syllogisms needed to prove PPIs ${ }^{81}$ than to a consensus on the syllogisms to give a strong proof of DI. In the case of GJB2/GJB6 and deafness, a statistical method of proof (high rate of co-occurrence of heterozygous mutations), and evidence for interaction of the two proteins turned out to be incomplete proof. ${ }^{465455}$

Development of commonly accepted rules of proof in medical genetics has been a slow process. Even in areas such as GLA and genome-wide association studies, in which rigorous statistics can be applied, it took years to establish standards (LOD score thresholds, NPL score thresholds, association $\mathrm{p}$ values and q values) of proof. Establishing standards of proof may be at least twice as hard for DI. For example, one concept that was not applied consistently among the studies cited in online supplementary table S1 is that a proof of DI can be strengthened by comparing the genotypes at the two disease-associated loci/genes of the affected individuals to the genotypes of as many unaffected first-degree relatives as possible.

In conclusion, the collection here of known human DI examples provides a basis to identify new examples. Key ingredients to a convincing proof of DI include: evidence of proteinprotein or protein-DNA interaction for the two proteins or genes, pedigree data, animal models or very specific functional experiments. HTS is a tool to identify quickly the possible genes in a case of DI, especially when the genes are not obvious candidates, but HTS alone does not provide these three key ingredients to proving the mode of inheritance.

Acknowledgements This research was supported by the Intramural Research Program of the National Institutes of Health (NIH), NLM. Thanks to my NIH colleagues Drs Andrew Cullinane, Thomas Friedman, Marjan Huizing, Anna Panchenko and Aleksandar Stojmirović for useful suggestions. Thanks to Daniel Schäffer (Takoma Park Middle School Magnet Program) for help with the Figures. Thanks to two anonymous referees who made numerous insightful suggestions, including several additional pertinent references, which tangibly improved this review.

Contributors AAS did the research and wrote the manuscript.

Funding National Institutes of Health, Intramural Research Program. Competing interests None.

Provenance and peer review Commissioned; externally peer reviewed.

Open Access This is an Open Access article distributed in accordance with the Creative Commons Attribution Non Commercial (CC BY-NC 3.0) license, which permits others to distribute, remix, adapt, build upon this work non-commercially, and license their derivative works on different terms, provided the original work is properly cited and the use is non-commercial. See: http://creativecommons.org/ licenses/by-nc/3.0/

\section{REFERENCES}

1 Phillips PC. The language of gene interaction. Genetics 1998;149:1167-71.

2 Cordell HJ. Epistasis: what it means, what it doesn't mean, and statistical methods to detect it in humans. Hum Mol Genet 2002;11:2463-8. 
3 Defrise-Gussenhoven E. Hypothèes de dimérie et de non-pénétrance. Acta Genet 1962;12:65-96.

4 Strauch K, Fimmers R, Baur MP, Wienker TF. How to model a complex trait. 2. Analysis with two disease loci. Hum Hered 2003;56:200-11.

5 Dietter J, Spiegel A, an Mey D, Pflug HJ, Al-Kateb H, Hoffmann K, Wienker TF, Strauch K. Efficient two-trait-locus linkage analysis through program optimization and parallelization: application to hypercholesterolemia. Eur J Hum Genet 2004; 12:542-50

6 Génin E, Feingold J, Clerget-Darpoux F. Identifying modifier genes of monogenic disease: strategies and difficulties. Hum Genet 2008;124:357-68.

7 Kajiwara K, Berson EL, Dryja TP. Digenic retinitis pigmentosa due to mutations in the unlinked peripherin/RDS and ROM1 loci. Science 1994;264:1604-8.

8 Katsanis N, Ansley SJ, Badano JL, Eichers ER, Lewis RA, Hoskins BE, Scambler PJ, Davidson WS, Beales PL, Lupski JR. Triallelic inheritance in Bardet-Biedl syndrome, a Mendelian recessive disorder. Science 2001;293:2256-9.

9 Lerer I, Sagi M, Ben-Neriah Z, Wang T, Levi H, Abeliovich D. A deletion mutation in GJB6 cooperating with a GJB2 mutation in trans in non-syndromic deafness: a novel founder mutation in Ashkenazi Jews. Hum Mutat 2001;18:Mutation in Brief\#458 Online.

10 Badano JL, Katsanis N. Beyond Mendel: an evolving view of human genetic disease transmission. Nat Rev Genet 2002;3:779-89.

11 Ming JE, Muenke M. Multiple hits during early embryonic development: digenic diseases and holoprosencephaly. Am J Hum Genet 2002;71:1017-32.

12 Slavotinek A, Biesecker LG. Genetic modifiers in human development and malformation syndromes, including chaperone proteins. Hum Mol Genet 2003;12: R45-50.

13 Tam PKH, Garcia-Barceló M. Genetic basis of Hirschsprung's disease. Pediatr Surg Int 2009:25:543-58

14 Yan D, Liu X-Z. Modifiers of hearing impairment in humans and mice. Curr Genomics 2010;11:269-78.

15 Westphal V, Kjaergaard S, Schollen E, Martens K, Grunewald S, Schwartz M, Matthiis $\mathrm{G}$, Freeze $\mathrm{HH}$. A frequent mild mutation in ALG6 may exacerbate the clinical severity of patients with congenital disorder of glycosylation la (CDG-Ia) caused by phosphomannomutase deficiency. Hum Mol Genet 2002; 11:599-604.

16 Lemmers RJLF, Tawil R, Petek LM, Balog J, Block GJ, Santen GWE, Amell AM, van der Vliet PJ, Almomani R, Straasheijm KR, Krom YD, Klooster R, Sun Y, den Dunnen JT, Helmer Q, Donlin-Smith CM, Padberg GW, van Engelen BGM, de Greef JC, Aartsma-Rus AM, Frants RR, de Visser M, Desnuelle C, Sacconi $S$ Filippova GN, Bakker B, Bamshad MJ, Tapscott SJ, Miller DG, van der Maarel SM. Digenic inheritance of an SMCHD1 mutation and an FSHD-permissive D4Z4 allele causes facioscapulohumeral muscular dystrophy type 2. Nat Genet 2012;44:1370-4

17 Margolin DH, Kousi M, Chan YM, Lim ET, Schmahmann JD, Hadjivassiliou M, Hall JE, Adam I, Dwyer A, Plummer L, Aldrin SV, O'Rourke J, Kirby A, Lage K, Milunsky A, Milunsky JM, Chan J, Hedley-Whyte ET, Daly MJ, Katsanis N Seminara SB. Ataxia, dementia, and hypogonadotropism caused by disordered ubiquitination. New Engl J Med 2013;368:1992-2003.

18 McKusick VA. Mendelian Inheritance in Man and its online version, OMIM. Am J Hum Genet 2007;80:588-604.

19 Billingsley G, Bin J, Fieggen KJ, Duncan JL, Gerth C, Ogata K, Wodak SS, Traboulsi El, Fishman GA, Paterson A, Chitayat D, Knueppel T, Millán JM Mitchell GA, Deveault C, Héon E. Mutations in chaperonin-like BBS genes are a major contributor to disease development in a multiethnic Bardet-Biedl syndrome patient population. J Med Genet 2010;47:453-63.

20 Hjortshøj TD, Grønskov K, Philp AR, Nishimura DY, Riise R, Sheffield VC, Rosenberg T, Brøndum-Nielsen K. Bardet-Biedl syndrome in Denmark-report of 13 novel sequence variations in six genes. Hum Mutat 2010;31:429-36.

21 Box NF, Duffy DL, Chen W, Stark M, Martin NG, Sturm RA, Hayward NK. MC1R genotype modifies risk of melanoma in families segregating CDKN2A mutations. Am J Hum Genet 2001;69:765-73.

22 Berthet M, Denjoy I, Donger C, Demay L, Hammoude H, Klug D, Schulze-Bahr E, Richard P, Funke H, Schwartz K, Coumel P, Hainque B, Guicheney P. C-terminal HERG mutations: the role of hypokalemia and a KCNQ1-associated mutation in cardiac event occurrence. Circulation 1999:99:1464-70.

23 Westenskow P, Splawski I, Timothy KW, Keating MT, Sanguinetti MC. Compound mutations: a common cause of severe long-QT syndrome. Circulation 2004;109:1834-41

24 Tester DJ, Will ML, Haglund CM, Ackerman MJ. Compendium of cardiac channel mutations in 541 consecutive unrelated patients referred for long QT syndrome genetic testing. Heart Rhythm 2005;2:507-17.

25 Millat G, Chevalier P, Restier-Miron L, Da Costa A, Bouvagnet P, Kugener B, Fayol L, Gonzàlez Armengod C, Oddou B, Chanavat V, Froidefond E, Perraudin R, Rousson R, Rodriguez-Lafrasse C. Spectrum of pathogenic mutations and associated polymorphisms in a cohort of 44 unrelated patients with long QT syndrome. Clin Genet 2006;70:214-27.

26 Vatta M, Ackerman MJ, Ye B, Makielski JC, Ughanze EE, Taylor EW, Tester DJ, Balijepalli RC, Foell JD, Li Z, Kamp TJ, Towbin JA. Mutant caveolin-3 induces persistent late sodium current and is associated with long-QT syndrome. Circulation 2006;114:2104-12.

27 Zheng QY, Yan D, Ouyang XM, Du LL, Yu H, Chang B, Johnson KR, Liu XZ. Digenic inheritance of deafness caused by mutations in genes encoding cadherin 23 and protocadherin 15 in mice and humans. Hum Mol Genet 2005;14:103-11.

28 van de Steeg $E$, Stránecký V, Hartmannová H, Nosková L, Hřebíček M, Wagenaar $E$, van Esch A, de Waart DR, Elferink RP Oude, Kenworthy KE, Sticová E, al-Edreesi M, Knisely AS, Kmoch S, Jirsa M, Schinkel AH. Complete OATP1B1 and OATP1B3 deficiency causes human Rotor syndrome by interrupting conjugated bilirubin reuptake into the liver. J Clin Invest 2012;122:519-28.

29 Riazuddin SA, Zaghloul NA, Al-Saif A, Davey L, Diplas BH, Meadows DN, Eghrari AO, Minear MA, Li Y-J, Klintworth GK, Afshari N, Gregory SG, Gottsch JD, Katsanis N. Missense mutations in TCF8 cause late-onset Fuchs corneal dystrophy and interact with FCD4 on chromosome 9p. Am J Hum Genet 2010;86:45-53.

30 Balciuniene J, Dahl N, Borg E, Samuelsson E, Koisti MJ, Pettersson U, Jazin EE. Evidence for digenic inheritance of non-syndromic hereditary hearing loss in a Swedish family. Am J Hum Genet 1998;63:786-93.

31 Balciuniene J, Dahl N, Jalonen P, Verhoeven K, Van Camp G, Borg E, Pettersson $U$, Jazin EE. Alpha-tectorin involvement in hearing disabilities: one gene -two phenotypes. Hum Genet 1999;105:211-16.

32 Dahia PLM, Hao K, Rogus J, Colin C, Pujana MAG, Ross K, Magoffin D, Aronin N Cascon A, Hayashida CY, Li C, Toledo SPA, Stiles CD, Familial Pheochromocytoma Consortium. Novel pheochromocytoma susceptibility loci identified by integrative genomics. Cancer Res 2005;65:9651-8.

33 Qin Y, Yao L, King EE, Buddavarapu K, Lenci RE, Chocron ES, Lechleiter JD, Sass M, Aronin N, Schiavi F, Boaretto F, Opocher G, Toledo RA, Toledo SPA Stiles C, Aguiar RCT, Dahia PLM. Germline mutations in TMEM127 confer susceptibility to pheochromocytoma. Nat Genet 2010;42:229-33.

34 Schork NJ, Boehnke M, Terwilliger JD, Ott J. Two-trait-locus linkage analysis: a powerful strategy for mapping complex genetic traits. Am J Hum Genet 1993;53:1127-36.

35 Fishelson $\mathrm{M}$, Geiger $\mathrm{D}$. Exact genetic linkage computations for general pedigrees. Bioinformatics 2002;18(Suppl):S189-8.

36 Neumann RJ, Rice JP. Two-locus models of disease. Genet Epidemiol 1992;9:347-65.

37 Li W, Reich J. A complete enumeration and classification of two-locus disease models. Hum Hered 2000;50:334-9.

38 Hallgrímsdóttir IB, Yuster DS. A complete classification of epistatic two-locus models. BMC Genet 2008;9:17.

39 Madsen AM, Ottman R, Hodge SE. Causal models for investigating complex genetic disease: II. what causal models can tell us about penetrance for additive, heterogeneity, and multiplicative two-locus models. Hum Hered 2011:72:63-72

40 Bansal V, Halpern AL, Axelrod N, Bafna V. An MCMC algorithm for haplotype assembly from whole-genome sequence data. Genome Res 2008;18:1336-46.

41 Aguiar D, Istrail S. HapCompass: a fast cycle basis algorithm for accurate haplotype assembly of sequence data. J Comput Biol 2012;19:577-90.

42 He D, Han B, Eskin E. Hap-seq: an optimal algorithm for haplotype phasing with imputation using sequencing data. J Comput Biol 2013;20:80-92.

43 Cullinane AR, Vilboux T, O'Brien K, Curry JA, Maynard DM, Carlson-Donohoe $H_{4}$ Ciccone C NISC Comparative Sequencing Program Markello TC, Gunay-Aygun M, Huizing M, Gahl WA. Homozygosity mapping and whole-exome sequencing to detect SLC45A2 and G6PC3 mutations in a single patient with oculocutaneous albinism and neutropenia. J Invest Dermatol 2001;131:2017-25.

44 Zheng QY, Scarborough JD, Zheng Y, Yu H, Choi D, Gillespie PG. Digenic inheritance of deafness caused by $8 \mathrm{~J}$ allele of myosin-VIIA and mutations in other Usher I genes. Hum Mol Genet 2012;21:2588-98.

45 Arnos KS, Welch KO, Tekin M, Norris WW, Blanton SH, Pandya A, Nance WE. A comparative analysis of the genetic epidemiology of deafness in the United States in two sets of pedigrees collected more than a century apart. Am J Hum Genet 2008:83:200-7

46 Wilch $E$, Zhu M, Burkhart KB, Regier M, Elfenbein JL, Fisher RA, Friderici KH. Expression of GJB2 and GJB6 is reduced in a novel DFNB1 allele. Am J Hum Genet 2006;79:174-9.

47 Vozzi D, Aaspõllu A, Athanasakis E, Berto A, Fabretto A, Licastro D, Külm M, Testa F, Trevisi P, Vahter M, Ziviello C, Martini A, Simonelli F, Banfi S, Gasparini P. Molecular epidemiology of Usher syndrome in Italy. Mol Vis 2011;17:1662-8.

48 Ahmed ZM, Riazuddin S, Aye S, Ali RA, Venselaar H, Anwar S, Belyantseva PP, Qasim M, Riazuddin S, Friedman TB. Gene structure and mutant alleles of PCDH15: nonsyndromic deafness DFNB23 and type 1 Usher syndrome. Hum Genet 2008;124:215-23.

49 Schultz JM, Yang Y, Caride AJ, Filoteo AG, Penheiter AR, Lagziel A, Morell RJ, Mohiddin SA, Fananapazir L, Madeo AC, Penniston JT, Griffith AJ. Modification of human hearing loss by plasma-membrane calcium pump PMCA2. N Engl J Med 2005;352:1557-64.

50 Pallares-Ruiz N, Blanchet P, Mondain M, Claustres M, Roux A-F. A large deletion including most of GJB6 in recessive non syndromic deafness: a digenic effect? Eur J Hum Genet 2002;10:72-6. 
51 del Castillo I, Villamar M, Moreno-Pelayo MA, del Castillo FJ, Álvarez A, Tellería D, Menéndez I, Moreno F. A deletion involving the connexin 30 gene in nonsyndromic hearing impairment. N Engl J Med 2002;24:243-9.

52 del Castillo FJ, Rodríguez-Ballesteros M, Alvarez A, Hutchin T, Leonardi E, de Oliveira CA, Azaiez H, Brownstein Z, Avenarius MR, Marlin S, Pandya A, Shahin H, Siemering KR, Weil D, Wuyts W, Aguirre LA, Martín Y, Moreno-Pelayo MA, Villamar M, Avraham KB, Dahl HH, Kanaan M, Nance WE, Petit C, Smith RJ, Van Camp G, Sartorato EL, Murgia A, Moreno F, del Castillo I. A novel deletion involving the connexin-30 gene, del(GJB6-d13s1854), found in trans with mutations in the GJB2 gene (connexin-26) in subjects with DFNB1 non-syndromic hearing impairment. J Med Genet 2005;42:588-94.

53 Liu X-Z, Yuan Y, Yan D, Ding EH, Ouyang XM, Fei Y, Tang W, Yuan H, Chang Q, Du LL, Zhang X, Wang G, Ahmad S, Kang DY, Lin X, Dai P. Digenic inheritance of non-syndromic deafness caused by mutations at the gap junction proteins $\mathrm{C} \times 26$ and Cx31. Hum Genet 2009;125:53-62.

54 Rodriguez-Paris J, Schrijver I. The digenic hypothesis unraveled: the GJB6 del (GJB6-D13S1830) mutation causes allele-specific loss of GJB2 expression in cis. Biochem Biophys Res Commun 2009;389:354-9.

55 Rodriguez-Paris J, Tamayo ML, Gelvez N, Schrijver I. Allele-specific impairment of GJB2 expression by GJB6 deletion del(GJB6-D13S1854). PLOS ONE 2011;6: e21665.

56 Saudou F. A "so cilia" network: cilia proteins start "social" networking. I Clin Invest 2012;122:1198-201.

57 Brugmann SA, Allen NC, James AW, Mekonnen Z, Madan E, Helms JA. A primary cilia-dependent etiology for midline facial disorders. Hum Mol Genet 2010;19:1577-92.

58 McCabe MJ, Gaston-Massuet C, Tziaferi V, Gregory LC, Alatzoglou KS, Signore M, Puelles E, Gerrelli D, Faroogi IS, Raza J, Walker J, Kavanaugh SI, Tsai P-S, Pitteloud N, Martinez-Barbera J-P, Dattani MT. Novel FGF8 mutations associated with recessive holoprosencephaly, craniofacial defects, and hypothalamo-pituitary dysfunction. J Clin Endocrinol Metab 2011;96:E1709-18.

59 Nachury MV, Loktev AV, Zhang Q, Westlake CJ, Peränen J, Merdes A, Slusarski DC, Scheller RH, Bazan JF, Sheffield VC, Jackson PK. A core complex of BBS proteins cooperates with the GTPase Rab8 to promote ciliary membrane biogenesis. Cell 2007;129:1201-13.

60 Seo S, Baye LM, Schulz NP, Beck JS, Zhang Q, Slusarski DC, Sheffield VC. BBS6, BBS10, and BBS12 form a complex with CCT/TRiC family chaperonins and mediate BBSome assembly. Proc Natl Acad Sci USA 2010;107:1488-93.

61 Katsanis N, Eichers ER, Ansley SJ, Lewis RA, Kayserili H, Hoskins BE, Scambler PJ, Beales PL, Lupski JR. BBS4 is a minor contributor to Bardet-Biedl syndrome and may also participate in triallelic inheritance. Am J Hum Genet 2002;71:22-9.

62 Beales PL, Badano JL, Ross AJ, Ansley SJ, Hoskins BE, Kirsten B, Mein CA, Froguel P, Scambler PJ, Lewis RA, Lupski JR, Katsanis N. Genetic interaction of BBS1 mutations with alleles at other BBS loci can result in non-Mendelian Bardet-Biedl syndrome. Am J Hum Genet 2003;72:1187-99.

63 Hichri H, Stoetzel C, Laurier V, Caron S, Sigaudy S, Sarda P, Hamel C, Martin-Coignard D, Gilles M, Leheup B, Holder M, Kaplan J, Bitoun P, Lacombe D, Verloes A, Bonneau D, Perrin-Schmitt F, Brandt C, Besancon A-F, Mandel J-L, Cossée M, Dollfus H. Testing for triallelism: analysis of six BBS genes in a Bardet-Biedl syndrome family cohort. Eur I Hum Genet 2005;13:607-16.

64 Badano JL, Leitch CC, Ansley SJ, May-Simera H, Lawson S, Lewis RA, Beales PL, Dietz HC, Fisher S, Katsanis N. Dissection of epistasis in oligogenic Bardet-Biedl syndrome. Nature 2006;439:326-30

65 Lee JE, Silhavy JL, Zaki MS, Schroth J, Bielas SL, Marsh SE, Olvera J, Brancati F, lannicelli M, Ikegami K, Schlossman AM, Merriman B, Attié-Bitach T, Logan CV, Glass IA, Cluckey A, Louie CM, Lee JH, Raynes HR, Rapin I, Castroviejo IP, Setou M, Barbot C, Boltshauser E, Nelson SF, Hildebrandt F, Johnson CA, Doherty DA, Valente EM, Gleeson JG. CEP41 is mutated in Joubert syndrome and is required for tubulin glutamylation at the cilium. Nat Genet 2012;44:193-9.

66 Rachel RA, May-Simera HL, Veleri S, Gotoh N, Choi BY, Murga-Zamalloa C, McIntyre JC, Marek J, Lopez I, Hackett AN, Zhang J, Brooks M, den Hollander Al, Beales PL, Li T, Jacobson SG, Sood R, Martens JR, Liu P, Friedman TB, Khanna H, Koenekoop RK, Kelley MW, Swaroop A. Combining Cep290 and Mkks ciliopathy alleles in mice rescues sensory defects and restores ciliogenesis. I Clin Invest 2012;122:1233-45.

67 Thiel C, Kessler K, Giessl A, Dimmler A, Shalev SA, von der Haar S, Zenker M, Zahnleiter D, Stöss H, Beinder E, Jamra R Abou, Ekici AB, Schröder-Kreß N, Aigner T, Kirchner T, Reis A, Brandstätter JH, Rauch A. NEK1 mutations cause short-rib polydactyly syndrome type Majewski. Am J Hum Genet 2011;88:106-14.

68 Koziell A, Grech V, Hussain S, Lee G, Lenkkeri U, Tryggvason K, Scambler P. Genotype/phenotype correlations of NPHS1 and NPHS2 mutations in nephrotic syndrome advocate a functional inter-relationship in glomerular filtration. Hum Mol Genet 2002;11:379-88.

69 Dodé C, Teixeira L, Levilliers J, Fouveaut C, Bouchard P, Kottler M-L, Lespinasse J, Lienhardt-Roussie A, Mathieu M, Moerman A, Morgan G, Murat A, Toublanc J-E, Wolczynski S, Delpech M, Petit C, Young J, Hardelin J-P. Kallmann syndrome: mutations in the genes encoding prokineticin-2 and prokineticin receptor-2. PLoS Genet 2006;2:e175.
70 Pitteloud N, Quinton R, Pearce S, Raivio T, Acierno J, Dwyer A, Plummer L, Hughes V, Seminara S, Cheng Y-Z, Li W-P, Maccoll G, Eliseenkova AV, Olsen SK, Ibrahimi OA, Hayes FJ, Boepple P, Hall JE, Bouloux P, Mohammadi M, Crowley W Jr. Digenic mutations account for variable phenotypes in idiopathic hypogonadotropic hypogonadism. J Clin Invest 2007;117:457-63.

71 Miraoui H, Dwyer AA, Sykiotis GP, Plummer L, Chung W, Feng B, Beenken A, Clarke J, Pers TH, Dworzynski P, Keefe K, Niedziela M, Raivio T, Crowley WF Jr, Seminara SB, Quinton R, Hughes VA, Kumanov P, Young J, Yialamas MA, Hall JE, Van Vliet G, Chanoine J-P, Rubenstein J, Mohammadi M, Tsai P-S, Sidis Y, Lage K, Pitteloud N. Mutations in FGF17, IL17RD, DUSP6, SPRY4, and FLRT3 are identified in individuals with congenital hypogonadotropic hypogonadism. Am J Hum Genet 2013;92:725-43.

72 Riazuddin S, Castelein CM, Ahmed ZM, Lalwani AK, Mastroianni MA, Naz S, Smith TN, Liburd NA, Friedman TB, Griffith AJ, Riazuddin S, Wilcox ER. Dominant modifier DFNM1 suppresses recessive deafness DFNB26. Nat Genet 2000;26: 431-4.

73 Knoblauch H, Müller-Myhsok B, Busjahn A, Ben Avi L, Bähring S, Baron H, Heath SC, Uhlmann R, Faulhaber HD, Shpitzen $S$, Aydin $A$, Reshef $A$, Rosenthal M, Eliav O, Mühl A, Lowe A, Schurr D, Harats D, Jeschke E, Friedlander $\mathrm{Y}$, Schuster $\mathrm{H}$, Luft FC, Leitersdorf E. A cholesterol-lowering gene maps to chromosome 13q. Am J Hum Genet 2000;66:157-66.

74 Al-Kateb H, Bähring S, Hoffmann K, Strauch K, Busjahn A, Nürnberg G, Jouma M, Bautz EK, Dresel HA, Luft FC. Mutation in the ARH gene and a chromosome 13q locus influence cholesterol levels in a new form of digenic-recessive familial hypercholesterolemia. Circ Res 2002:90:951-8.

75 Basit S, Wali A, Aziz A, Muhammad N, Jelani M, Ahmad W. Digenic inheritance of an autosomal recessive hypotrichosis in two consanguineous pedigrees. Clin Genet 2011;79:273-81.

76 Oprea GE, Kröber S, McWhorter ML, Rossoll W, Müller S, Krawczak M, Bassell GJ, Beattie CE, Wirth B. Plastin 3 is a protective modifier of autosomal recessive spinal muscular atrophy. Science 2008;320:524-7.

77 Qin M, Hayashi H, Oshima K, Tahira T, Hayashi K, Kondo H. Complexity of the genotype-phenotype correlation in familial exudative vitreoretinopathy with mutations in the LRP5 and/or FZD4 genes. Hum Mutat 2005;26: 104-12.

78 Addis M, Meloni C, Tosetto E, Ceol M, Cristofaro R, Melis MA, Vercelloni P, Del Prete D, Marra G, Anglani F. An atypical Dent's disease phenotype caused by co-inheritance of mutations at CLCN5 and OCRL genes. Eur I Hum Genet 2013:21:687-90.

79 Carlton VEH, Harris BZ, Puffenberger EG, Batta AK, Knisely AS, Robinson DL, Strauss KA, Shneider BL, Lim WA, Salen G, Morton DH, Bull LN. Complex inheritance of familial hypercholanemia with associated mutations in TJP2 and BAAT. Nat Genet 2003:34:91-6.

80 Ebermann I, Walger M, Scholl HPN, Issa P Charbel, Lüke C, Nürnberg G, Lang-Roth R, Becker C, Nürnberg P, Bolz HJ. Truncating mutation of the DFNB59 gene causes cochlear hearing impairment and central vestibular dysfunction. Hum Mutat 2007;28:571-7.

81 Shoemaker BA, Panchenko AR. Deciphering protein-protein interactions part I. experimental techniques and databases. PLoS Comput Biol 2007;3:e42.

82 Razick S, Maglaras G, Donaldson IM. iReflndex: a consolidated protein interaction database with provenance. BMC Bioinformatics 2008;9:405.

83 Turner B, Razick S, Turinsky AL, Vlasblom J, Crowdy EK, Cho E, Morrison K, Donaldson IM, Wodak SJ. iRefWeb: interactive analysis of consolidated protein interaction data and their supporting evidence. Database 2010;2010:baq023.

84 Stojmirović A, Yu Y-K. ppiTrim: constructing non-redundant and up-to-date interactomes. Database 2011;2011:bar036.

85 Glissen C, Hoischen A, Brunner HG, Veltman JA. Disease gene identification strategies for exome sequencing. Eur I Hum Genet 2012;20:490-7.

86 Lupski JR, Belmont JW, Boerwinkle E, Gibbs RA. Clan genomics and the complex architecture of human disease. Cell 2011;147:32-43.

87 Yang T, Vidarsson H, Rodrigo-Blomqvist S, Rosengren SS, Enerbäck S, Smith RJH. Transcriptional control of SLC26A4 is involved in Pendred syndrome and nonsyndromic enlargement of vestibular aqueduct (DFNB4). Am J Hum Genet 2007:80:1055-63.

88 Adato A, Kalinski H, Weil D, Chaib H, Korostishevsky M, Bonne-Tamir B. Possible interaction between USH1B and USH3 gene products as implied by apparent digenic recessive inheritance. Am J Hum Genet 1999;65:261-5.

89 Ebermann I, Phillips JB, Liebau MC, Koenekoop RK, Schermer B, Lopez I, Schäfer $E$, Roux A-F, Dafinger $C$, Bernd $A$, Zrenner $E$, Claustres $M$, Blanco B, Nürnberg G, Nürnberg P, Ruland R, Westerfield M, Benzing T, Bolz HJ. PDZD7 is a modifier of retinal disease and a contributor to digenic Usher syndrome. J Clin Invest 2010;120:1812-23.

90 Schlingmann KP, Konrad M, Jeck N, Waldegger P, Reinalter SC, Holder M, Seyberth HW, Waldegger $\mathrm{S}$. Salt wasting and deafness resulting from mutations in two chloride channels. N Engl I Med 2004;350:1314-19.

91 Auricchio A, Griseri P, Carpentieri ML, Betsos N, Staiano A, Tozzi A, Priolo M, Thompson H, Bocciardi R, Romeo G, Ballabio A, Ceccherini I. Double heterozygosity for a RET substitution interfering with splicing and an EDNRB 
missense mutation in Hirschsprung disease. Am J Hum Genet 1999; 64:1216-21.

92 Tang $\mathrm{B}$, Xiong $\mathrm{H}$, Sun $\mathrm{P}$, Zhang $\mathrm{Y}$, Wang $\mathrm{D}$, Hu Z, Zhu Z, Ma H, Pan Q, Xia JH, Xia K, Zhang Z. Association of PINK1 and DJ-1 confers digenic inheritance of early-onset Parkinson's disease. Hum Mol Genet 2006;15:1816-25.

93 Vincent AL, Billingsley G, Buys Y, Levin AV, Priston M, Trope G, Williams-Lyn D, Héon E. Digenic inheritance of early-onset glaucoma: CYP1B1, a potential modifier gene. Am J Hum Genet 2002;70:448-60.

94 Morell R, Spritz RA, Ho L, Pierpont J, Guo W, Friedman TB, Asher JH Jr. Apparent digenic inheritance of Waardenburg syndrome type 2 (WS2) and autosomal recessive ocular albinism (AROA). Hum Mol Genet 1997;6:659-64.

95 Hutton SM, Spritz RA. A comprehensive genetic study of autosomal recessive ocular albinism in Caucasian patients. Invest Ophthalmol Vis Sci 2008;49:868-72.

96 Floeth M, Bruckner-Tuderman L. Digenic junctional epidermolysis bullosa: mutations in COL17A1 and LAMB3 genes. Am J Hum Genet 1999;65:1530-7.

97 Bolliger-Stucki B, Lord ST, Furlan M. Fibrinogen Milano XII: a dysfunctional variant containing 2 amino acid substitutions, A $\alpha$ R16C and $\gamma$ G165R. Blood 2001:98:351-7.

98 Pei Y, Paterson AD, Wang KR, He N, Hefferton D, Watnick T, Germino GG, Parfrey P, Somlo S, St George-Hyslop P. Bilineal disease and trans-heterozygotes in autosomal dominant polycystic kidney disease. Am J Hum Genet 2001;68:355-63.

99 Font-Llitjós M, Jiménez-Vidal M, Bisceglia L, Di Perna M, de Sanctis L, Rousaud F, Zelante L, Palacín M, Nunes V. New insights into cystinuria: 40 new mutations, genotype-phenotype correlation, and digenic inheritance causing partial phenotype. J Med Genet 2005;42:58-68.

100 Savage DB, Agostini M, Barroso I, Gurnell M, Luan J, Meirhaeghe A, Harding A-H, Ihrke G, Rajanayagam O, Soos MA, George S, Berger D, Thomas EL, Bell JD, Meeran K, Ross RJ, Vidal-Puig A, Wareham NJ, O'Rahilly S, Chatterjee VK, Schafer AJ. Digenic inheritance of severe insulin resistance in a human pedigree. Nat Genet 2002;31:379-84.

101 Shastry BS, Trese MT. Cosegregation of two unlinked mutant alleles in some cases of autosomal dominant familial exudative vitreoretinopathy. Eur I Hum Genet 2004;12:79-82

102 Berger M, Mattheisen M, Kulle B, Schmidt H, Oldenburg J, Bickeböller $H_{\text {, }}$ Walter U, Lindner TH, Strauch K, Schambeck CM. High factor VIII levels in venous thromboembolism show linkage to imprinted loci on chromosomes 5 and 11. Blood 2005;105:638-44.

103 Meggouh F, de Visser M, Arts WFM, De Coo RIFM, van Schaik IN, Baas F. Early onset neuropathy in a compound form of Charcot-Marie-Tooth disease. Ann Neurol 2005;57:589-91.

104 Hodapp JA, Carter GT, Lipe HP, Michelson SJ, Kraft GH, Bird TD. Double trouble in hereditary neuropathy: concomitant mutations in the PMP-22 gene and another gene produce novel phenotypes. Arch Neurol 2006;63:112-17.

105 Vital A, Latour P, Sole G, Ferrer X, Rouanet M, Tison F, Vital C, Goizet C. A French family with Charcot-Marie-Tooth disease related to simultaneous heterozygous MFN2 and GDAP1 mutations. Neuromuscul Disord 2012;22:735-41.

106 Muntoni F, Bonne G, Goldfarb LG, Mercuri E, Piercy RJ, Burke M, Yaou RB, Richard $P$, Récan D, Shatunov A, Sewry CA, Brown SC. Decreased severity in dominant Emery Dreifuss is increased by mutations in both emerin and desmin proteins. Brain 2006;129:1260-8.

107 Santos M, Clevers HC, Marx JJ. Mutations of the hereditary hemochromatosis candidate gene HLA-H in porphyria cutanea tarda. N Engl J Med 1997:336:1327-8.

108 Harraway JR, Florkowski CM, Sies C, George PM. Dual porphyria with mutations in both the UROD and HMBS genes. Ann Clin Biochem 2006:43:80-2.

109 Akagi R, Inoue R, Muranaka S, Tahara T, Taketani S, Anderson KE, Phillips JD, Sassa S. Dual gene defects involving $\delta$-aminolaevulinate dehydratase and coproporphyrinogen oxidase in a porphyria patient. $\mathrm{Br} J$ Haematol 2006; 132:237-43.
110 Baulac S, Picard F, Herman A, Feingold J, Genin E, Hirsch E, Prud'homme JF, Baulac M, Brice A, LeGuern E. Evidence for digenic inheritance in a family with both febrile convulsions and temporal lobe epilepsy implicating chromosome 18qter and 1q25-q31. Ann Neurol 2001;49:786-92.

111 Merryweather-Clarke AT, Cadet E, Bomford A, Capron D, Viprakasit V, Miller A, McHugh PJ, Chapman RW, Pointon JJ, Wimhurst VLC, Livesey KJ, Tanphaichitr V, Rochette J, Robson $\mathrm{KJH}$. Digenic inheritance of mutations in HAMP and HFE results in different types of haemochromatosis. Hum Mol Genet 2003;12: 2241-7.

112 Van Goethem G, Löfgren A, Dermaut B, Ceuterick C, Martin J-J, Van Broeckhoven C. Digenic progressive external ophthalmoplegia in a sporadic patient: recessive mutations in POLG and C10orf2/Twinkle. Hum Mutat 2003;22:175-6.

113 Ito M, Yamakawa K, Sugawara T, Hirose S, Fukuma G, Kaneko S. Phenotypes and genotypes in epilepsy with febrile seizures plus. Epilepsy Res 2006;70(Suppl 1): S199-205.

114 Pinto D, Kasteleijn-Nolst Trenité DGA, Cordell HJ, Mattheisen M, Strauch K, Lindhout $D$, Koeleman BPC. Explorative two-locus linkage analysis suggests a multiplicative interaction between the 7q32 and 16p13 myoclonic seizures-related photosensitivity loci. Genet Epidemiol 2007;31:42-50.

115 Naveed M, Nath SK, Gaines M, Al-Ali MT, Al-Khaja N, Hutchings D, Golla J, Deutsch S, Bottani A, Antonarakis SE, Ratnamala U, Radhakrishna U. Genomewide linkage scan for split-hand/foot malformation with long-bone deficiency in a large Arab family identifies two novel susceptibility loci on chromosomes 1q42.2-q43 and 6q14.1. Am J Hum Genet 2007;80:105-11.

116 Bröer S, Bailey CG, Kowalczuk S, Ng C, Vanslambrouck JM, Rodgers H, Auray-Blais C, Cavanaugh JA, Bröer A, Rasko JE. Iminoglycinuria and hyperglycinuria are discrete human phenotypes resulting from complex mutations in proline and glycine transporters. J Clin Invest 2008;118:3881-92.

117 Burdon KP, Coster DJ, Charlesworth JC, Mills RA, Laurie KJ, Giunta C, Hewitt AW, Latimer $\mathrm{P}$, Craig JE. Apparent autosomal dominant keratoconus in a large Australian pedigree accounted for by digenic inheritance of two novel loci. Hum Genet 2008;124:379-86.

118 Trabelsi M, Kavian N, Daoud F, Commere V, Deburgrave N, Beugnet C, Llense S, Barbot JC, Vasson A, Kaplan JC, Leturcq F, Chelly J. Revised spectrum of mutations in sarcoglycanopathies. Eur J Hum Genet 2008;16:793-803.

119 Nadeau A, Kinali M, Main M, Jimenez-Mallebrera C, Aloysius A, Clement E, North B, Manzur AY, Robb SA, Mercuri E, Muntoni F. Natural history of Ullrich congenital muscular dystrophy. Neurology 2009;73:25-31.

120 Li Q, Grange DK, Armstrong NL, Whelan AJ, Hurley MY, Rishavy MA, Hallgren KW, Berkner KL, Schurgers LJ, Jiang Q, Uitto J. Mutations in the GGCX and $A B C C 6$ genes in a family with pseudoxanthoma elasticum-like phenotypes. $J$ Invest Dermatol 2009;129:553-63.

121 Brusse E, Majoor-Krakauer D, de Graaf BM, Visser GH, Swagemakers S, Boon AJ, Oostra BA, Bertoli-Avella AM. A novel 16p locus associated with BSCL2 hereditary motor neuronopathy: a genetic modifier? Neurogenetics 2009;10:289-97.

122 Wang Y, Li X, Zhu W-L, Guo J-Z, Song X-M, Li S-Q, Li Y. Genome-wide and interaction linkage scan for nonsyndromic cleft lip with or without cleft palate in two multiplex families in Shengyang, China. Biomed Env Sci 2010;23: $363-73$.

123 Kelberman D, Islam L, Holder SE, Jacques TS, Calvas P, Hennekam RC, Nischal KK, Sowden JC. Digenic inheritance of mutations in FOXC1 and PITX2: correlating transcription factor function and Axenfeld-Rieger disease severity. Hum Mutat 2011:32:1144-52.

124 Morak M, Massdorf T, Sykora H, Kerscher M, Holinski-Feder E. First evidence for digenic inheritance in hereditary colorectal cancer by mutations in the base excision repair genes. Eur I Cancer 2011;47:1046-55.

125 Padalon-Brauch G, Ben Amitai D, Vodo D, Harel A, Sarig O, Sprecher E, Mashiah J. Digenic inheritance in epidermolysis bullosa simplex. J Invest Dermatol 2012;132:2852-4. 